DOBROCHNA HILDEBRANDT-WYPYCH

Uniwersytet im. Adama Mickiewicza

$w$ Poznaniu

\title{
NEOLIBERALIZM I DESEKULARYZACJA JAKO DWA WYMIARY REFORM EDUKACJI WE WSPÓŁCZESNEJ TURCJI
}

\begin{abstract}
Hildebrandt-Wypych Dobrochna, Neoliberalizm i desekularyzacja jako dwa wymiary reform edukacji we wspótczesnej Turcji [Neoliberalism and Desecularisation as Two Dimensions of Educational Reforms in Contemporary Turkey]. Studia Edukacyjne nr 43, 2017, Poznań 2017, pp. 21-41. Adam Mickiewicz University Press. ISSN 1233-6688. DOI: 10.14746/se.2017.43.2

The text focuses on neoliberalism and desecularisation as two major dimensions of social and educational change in contemporary Turkey. Key educational reforms of recent years are discussed from the perspective of the conservative-religious turn in Turkish society and politics, particularly noticeable from 2002, i.e. the first AKP electoral success. However, the origins of the Oriental-Western duality of identity, as well as the "use" of Islam for strengthening the new Turkish national identity, can be traced back to Kemalist policy of secularisation and modernization of Turkish society. This peculiar merge of neoliberal and religious symbols is also visible in education, where selforientalizing, nationalizing and secularizing discourses mix with the pressure on selection, effectiveness and competition in the "western" style. Therefore, the rising importance of faith schools in present day Turkey has also been discussed in the light of the historical Kemalist concept of transformation of Islam and the creation of national, state-controlled "civic religion".
\end{abstract}

Key words: Turkey, educational reforms, faith schools, Imam Hatip, neolibaralism, secularisation, desecularisation, educational policy

\section{Kontekst teoretyczny}

Adekwatną dla podejmowanej problematyki zmian edukacyjnych we współczesnej Turcji perspektywą teoretyczną jest ujęta przez Edwarda Saida analiza kulturowych, politycznych, a także społeczno-ekonomicznych związków Zachodu z islamem, przedstawiona najpełniej w klasycznym już, wydanym dziele Edwarda Saida: Orientalism. Said sięgając do okresu kolo- 
nializmu, wskazuje na źródła marginalizacji kultury muzułmańskiej, oparte na „etnocentrycznej, rasistowskiej reprezentacji Arabów i muzułmanów na Zachodzie"1. Ideologiczny wymiar „orientalizmu" charakteryzuje Said następująco:

Ludzie Orientu, podobnie jak wszystkie inne ludy na różne sposoby naznaczone jako zacofane, zdegradowane, niekulturalne i zapóźnione, ujmowano $\mathrm{w}$ ramy pojęciowe sklecone $\mathrm{z}$ determinizmu biologicznego oraz politycznej moralistyki. Toteż Azjata został połączony z tymi elementami społeczeństwa zachodniego (takimi jak skazańcy, szaleni, kobiety, ubodzy), dla których wspólną była tożsamość dająca się opisać najlepiej jako żałośnie obcy. (...) rozpatrywano ich [Azjatów - DH-W] nie jako obywateli czy nawet ludzi, ale jako problemy, które trzeba rozwiązać czy ograniczyć, albo - jako że mocarstwa kolonialne otwarcie pragnęły ich ziem - które trzeba przejąć ${ }^{2}$.

Obraz Wschodu dominujący na Zachodzie przybrał według E. Saida kształt - wyrastającego z kolonializmu i imperializmu - orientalizmu. W najogólniejszym rozumieniu orientalizm stanowi „styl myślenia oparty na ontologicznym i epistemologicznym rozróżnieniu między Orientem a (...) Okcydentem"3. W jego wyniku Wschód, konstruowany jako - w najlepszym wypadku - tradycyjny, w najgorszym zaś - wsteczny i zacofany, staje się całkowitym zaprzeczeniem Zachodu. Proces „wyobcowania” (othering) Wschodu polega właśnie na przyjęciu, dzięki przeróżnym tekstom kulturowym (poezji, prozie, tekstom filozoficznym bądź manifestom politycznym), zestawu „mitów, wyobrażeń i pojęć dostępnych dla każdego, kto próbuje myśleć o tym, co znajduje się na wschód od linii demarkacyjnej"4. Orientalizm, jako europejska wizja Wschodu, jest powszechnie aprobowany na Zachodzie, gdzie stanowi „koło zamachowe” przeróżnych stereotypów. Jednak, jak podkreśla Said, orientalizujące dyskursy zostały też przyjęte na Wschodzie, stając się kluczowym narzędziem podporządkowania.

Rozpoczęty w XIX wieku przez Młodoturków ${ }^{5}$ proces westernizacji ogarnął wszystkie sfery życia - od sztuki, poprzez prawo, zwyczaje życia

${ }^{1}$ M. Castells, Siła tożsamości, Warszawa 2009, s. 137.

2 Tamże.

${ }^{3}$ E. Said, Orientalism, New York 1978, s. 2-3.

4 J. Kieniewicz, Spotkania Wschodu, Gdańsk 1999, s. 43.

${ }^{5}$ Ruch młodoturecki działał na przełomie XIX i XX w., a jego trzon stanowiło pokolenie reformatorów-pozytywistów, wierzących w ideę postępu młodych Osmanów, wykształconych w zachodnim systemie edukacyjnym. Zasadniczym celem Młodoturków było obalenie monarchii osmańskiej i modernizacja państwa w duchu zachodnim. Z szeregów tego ruchu politycznego o później wyraźnie nacjonalistycznym i militarystycznym charakterze wywodzi się m.in. Mustafa Kemal (Atatürk), który w 1922 r. zniósł sułtanat i został pierwszym prezydentem świeckiej Republiki Tureckiej (por. The Princeton Encyclopedia of Islamic Political Thought, red. G. Böwering, Princeton 2013, s. 601). 
codziennego, a także (a może przede wszystkim) edukację. Rewolucja kemalistów stanowiła prawdziwą zmianę cywilizacyjną, której najważniejszym komponentem była całkowita sekularyzacja instytucji edukacyjnych i prawnych. Przełomem w sferze prawnej było przyjęcie w 1926 roku szwajcarskiego Kodeksu cywilnego oraz włoskiego Kodeksu karnego. Zwłaszcza nowe prawo cywilne, znoszące poligamię, przyznające kobietom równe mężczyznom prawa spadkowe oraz dostęp do życia publicznego, „zamknęło drzwi do starej cywilizacji, a otworzyło te do cywilizacji współczesnej" jak stwierdził ówczesny minister sprawiedliwości, absolwent studiów prawniczych w Szwajcarii, Mahmut Esat ${ }^{6}$.

O „kemalistycznym ideale zwesternizowanego, świeckiego obywatela” pisze Umut Azak, przytaczający przykłady bezpośredniej interwencji w codzienne życie ludzi, zmierzające do sekularyzacji sfery publicznej oraz dostosowania do cywilizacji zachodniej (m.in. odgórne wprowadzenie w 1925 r. kapelusza jako właściwego dla mężczyzn nakrycia głowy i przymus rezygnacji z tradycyjnego fezu; przyjęcie europejskiego czasu i kalendarza w 1926 r.; zastąpienie alfabetu arabskiego łacińskim w 1928 r.; wprowadzenie europejskiego systemu miar i wag w 1931 r.).

Odgórne ograniczenie połączeń między nowymi pokoleniami a starym światem islamskim uniemożliwiało (a przynajmniej znacznie ograniczało) bezpośredni dostęp do symbolicznej sfery otomańskiej przeszłości. Jak pisze U. Azak, „pozbycie się wpływów kultury islamskiej/arabskiej poprzez przyjęcie Europy jako wzoru stanowiło nadrzędny cel kemalistycznego nacjonalizmu"7. Autor cytuje w tym kontekście słowa redaktora najbardziej znanej „tuby propagandowej” Kemalistów, gazety „Suwerenność Narodowa” (tur. Hâkimiyet-i Milliye), iż „bycie zwesternizowanym oznaczało równoczesne uniknięcie bycia zarabizowanym; oznaczało bycie zturkizowanym (Turkified)"8. Cytat ten stanowi idealny przykład zakorzenionego w nacjonalizmie orientalizującego myślenia elit tureckich spod znaku Mustafy Kemala, a tym samym - opisywanego przez E. Saida - kreślenia „biało-czarnego” rozgraniczenia, hierarchicznej dychotomii między Zachodem a Wschodem. Nacjonalizm turecki stał się „awatarem orientalizmu”, podporządkowanym "naprawczemu” i "naukowemu” projektowi transformacji rdzennych mieszkańców w obywateli nowoczesnego, świeckiego państwa. Celem było

${ }^{6}$ U. Azak, Islam and Secularism in Turkey: Kemalism, Religion and the Nation State, New York 2010, s. 10.

7 Tamże, s. 11.

8 Tamże. 
„wskoczenie do pociągu do cywilizacji” z pomocą eurocentrycznych „dyscyplinujących narracji Zachodu"9.

Wprowadzeniem do tekstu poświęconego reformom edukacyjnym we współczesnej Turcji może być spostrzeżenie, że Turcja nie jest i nigdy nie była etnicznie i religijnie homogeniczna. Mimo to w ramach tureckiego projektu tworzenia nowoczesnego narodu kluczowe miejsce zajęło świeckie i jednolite etnicznie państwo narodowe, odgórnie powołane do życia przez „zwesternizowane” elity tureckie. Analizując turecki projekt narodotwórczy Welat Zeydanhoğlu dostrzega w nim dziedzictwo kolonializmu, które skłoniło niegdyś elity państwowe do odrzucenia różnorodności etnicznoreligijnej tego terytorium jako „wstecznej” i „wschodniej” (orientalnej). Efektem była nie tylko opresja względem kurdyjskiej tożsamości etnicznej, ale i często przemilczana - opresja względem religijnej (muzułmańskiej) części społeczeństwa tureckiego. W. Zeydanhoğlu cytuje w tym kontekście słowa samego Mustafy Kemala (Atatürka), wypowiedziane w 1925 roku podczas spotkania pantureckiej, nacjonalistycznej organizacji Türk Ocă̆i: „Panowie, niecywilizowani ludzie są skazani na zadeptanie przez ludzi cywilizowanych"10.

Spoglądając z perspektywy postkolonialnej, powstanie republikańskiej Turcji wsparte zostało założeniem o „zacofaniu” orientalnej kultury względem "nowoczesnego" i „progresywnego" Zachodu. Opisane przez E. Saida (1978) zjawisko stygmatyzacji Orientu, uznanie go za podrzędny względem Okcydentu i wyznaczenie jednoznacznej granicy między Wschodem a Zachodem zostało przyjęte za podstawę wszelkich konstrukcji świata, ludzi, zwyczajów i świadomości. „Orientalne obrazy”, w których „uwsteczniająca” tradycja wypierana jest przez "rozwijającą” nowoczesność, stały się koniecznym uzasadnieniem dla militarnej, politycznej, ekonomicznej i kulturowej dominacji Zachodu nad Wschodem. „Orientalne obrazy” wpływały też na ludzkie postrzeganie rzeczywistości i działanie. "Samo-orientalizujące" dyskursy pełniły też istotną funkcję polityczną w momencie przejmowania władzy, a następnie utrzymania jej przez Kemalistów: służyły podtrzymaniu nierównych stosunków władzy. Zastąpienie - spajającej wspólnotę - „wstecznej” religijności „nowoczesnym” nacjonalizmem stało się podstawą kultury politycznej, dzięki której dokonano „uniwersalizacji państwa narodowego jako najbardziej pożądanej formy wspólnoty politycz-

${ }^{9}$ W. Zeydanhoğlu, The White Turkish Man's Burden: Orientalism, Kemalism and the Kurds in Turkey, [w:] Neo-Colonial Mentalities in Contemporary Europe? Language and Discourse in the Construction of Identities, red. G. Rings, A. Ife, Cambridge Scholars Publishers, Newcastle UK, 2008, s. 155.

10 Tamże. 
nej"11. "Samo-orientalizujące" dyskursy stały się dominującym wymiarem nacjonalistycznej i autorytarnej „,wewnętrznej misji cywilizacyjnej”: kreowania nowych, zeuropeizowanych (narodowych) narracji historycznych ${ }^{12}$.

Doświadczeniem nowego, tureckiego obywatela było - i pozostaje nadal - orientalno-zachodnie „zdwojenie tożsamości”, określane przez współczesnych mianem „wewnętrznego dramatu” $\mathrm{i}$ „duchowej tragedii": obok nowej i pożądanej zachodniej/nowoczesnej jaźni funkcjonowała stara i tłumiona jaźń orientalna/tradycyjna. Ponadto, kemalistyczny nacjonalizm odwołuje się zarówno do etnicznych, jak i politycznych aspektów definiowania narodu, co sprawia, że definicja tureckości jest niejednoznaczna. $Z$ jednej strony mamy konstytucyjną ideę nacjonalizmu (tur. miliyetçilik), jednoczącą naród w ramach świeckiego państwa i wprowadzającą zasadę równości obywateli bez względu na wyznanie czy pochodzenie etniczne ${ }^{13}$. Z drugiej strony dominuje, zwłaszcza $\mathrm{w}$ tureckiej polityce wobec mniejszości, definiowanie tureckości w powiązaniu $\mathrm{z}$ - podporządkowanym państwu (republice) dziedzictwem islamu sunnickiego. Choć definiowanie grup mniejszościowych tylko na podstawie kryterium religijnego było sprzeczne z kemalistyczną ideą laicyzmu; obywatelstwo tureckie nawet w początkowych latach Republiki Tureckiej postrzegane było w znacznym stopniu przez pryzmat wyznania ${ }^{14}$. Mimo iż sekularyzm był zasadniczym komponentem cywilizacyjnej misji elit kemalistycznych, to tylko pozornie sprzecznym z nim elementem projektu Kemalistów była transformacja islamu. Mimo państwowych restrykcji i kontroli, „w praktyce państwo stworzyło sunnizm jako domyślną religię narodu i zwalczało reakcyjny islam za pomocą nacjonalizacji sunnizmu" 15 .

\section{Zwrot konserwatywno-religijny w polityce tureckiej}

Zdaniem części tureckich badaczy, u podstaw tureckiego projektu sekularyzacyjnego legł strach: odgórnie i programowo zaszczepiona w świadomości społecznej obawa przed „reakcyjnym islamem” (irtica), czyli przed -

11 Tamże.

12 Tamże.

${ }_{13}$ Konstytucja Republiki Tureckiej, Warszawa 2013, s. 51 http://libr.sejm.gov.pl/tek01/ txt/konst/turcja2013.pdf [dostęp: 21.07.2015].

${ }_{14}$ Umut Azak wspomina o stosowanej w polityce imigracyjnej wczesnej Republiki Tureckiej praktyce faworyzowania muzułmańskich Turków ponad Turków etnicznych (U. Azak, Islam and Secularism in Turkey, s. 13).

15 Tamże, s. 144. 
realizowaną przemocą i podstępem - islamizacją kraju. Jak podkreśla we wprowadzeniu do swojej niezwykle ciekawej monografii Umut Azak: „sekularyzm zdołano przekształcić $\mathrm{w}$ dyskurs internalizowany $\mathrm{w}$ dużej części społeczeństwa właśnie dzięki owej udanej reprodukcji strachu"16. Jednocześnie, towarzysząca owej "polityce strachu” próba degradacji tradycyjnej kultury religijnej okazała się niemożliwa, głównie z uwagi na powszechne przekonanie o trwałym powiązaniu „wielkości” Turcji z islamem. Fenomen określany mianem neootomanizmu (większego zaangażowania politycznego dzisiejszej Republiki Turcji w politykę krajów/regionów niegdyś znajdujących się pod rządami imperium osmańskiego) wyjaśnia Ziya Meral, mieszkający w Londynie turecki badacz i pisarz, ekspert w sprawach Turcji i Bliskiego Wschodu. Jego zdaniem,

Turcja cierpi na post-otomańską melancholię. Nie pogodziła się jeszcze z utratą imperium, a w narodzie nadal silne jest pragnienie rekonstrukcji wielkości narodu. Jest to nieodłączny element tureckiego stosunku do świata. My chcemy, aby świat dostrzegł turecką sławę oraz władzę na Bliskim Wschodzie, mamy przecież jedną z największych armii na świecie, jedną z najsilniejszych gospodarek w regionie.

O wskrzeszonej polityce neootomańskiej, a także o nowym neoliberalnym sposobie definiowania chwiejnej równowagi między "orientalnym" a „zachodnim" wymiarem tureckiej tożsamości narodowej możemy mówić od 2002 roku. Wówczas to zwycięska AKP - Partia Sprawiedliwości i Rozwoju (tur. Adalet ve Kalkmma Partisi) - z wielką determinacją zaczęła walczyć o wzmocnienie geopolityczne Turcji. Znamienne, iż na czele założonej w 2001 roku partii stanął ekonomista Recep Tayyip Erdoğan. W początkowym etapie rządów (lata 2002-2007) AKP skupiła się na kreowaniu gospodarczej prosperity, opartej na wolnorynkowych rozwiązaniach, potwierdzając jednocześnie polityczną gotowość do integracji Turcji z Unią Europejską, a nie nawiązując bezpośrednio do wzmocnienia miejsca religii (islamu) w życiu społecznym. Dzięki tak prowadzonej polityce wewnętrznej oraz zagranicznej AKP osiągnęła spektakularny sukces wyborczy, zdobywając aż 46,58\% głosów poparcia w wyborach parlamentarnych w 2007 roku. Zdaniem krytyków, dopiero od tego momentu można mówić o przejmowaniu instytucji państwowych, w tym także mediów, przez ludzi bezpośrednio powiązanych z kręgami religijnymi, w tym przede wszystkim z Ruchem Fethullah Gülena ${ }^{17}$. Przeni-

16 Tamże, s. XI. Zdaniem U. Azak, zasadnicze w kemalistycznej strategii pozbycia się irtica było przedefiniowanie islamu „,w oparciu o opozycję pomiędzy islamem tureckim (osobistym, oświeconym, racjonalnym i narodowym) a islamem reakcyjnym (politycznym, wstecznym, zabobonnym, arabskim)".

17 Fethullah Gülen Movement. 
kaniu wartości konserwatywno-religijnych do instytucji gospodarczych, politycznych (m.in. władzy legislacyjnej i sądowniczej) towarzyszyła presja wobec tych osób i grup społecznych, które nie popierały polityki rządowej, zwłaszcza w partiach opozycyjnych (takich jak prokurdyjska Ludowa Partia Demokratyczna - HDP), wśród przedsiębiorców oraz w mediach ${ }^{18}$. Zdecydowana większość społeczeństwa sprzyjała jednak realizowanej przez AKP wizji państwa, udzielając partii jeszcze większego niż poprzednio, prawie 50-procentowego poparcia w wyborach parlamentarnych w 2011 roku. Nawet protesty przeciwko bezlitośnie neoliberalnej polityce gospodarczej oraz przeciwko systematycznej rekonstrukcji życia ekonomicznego, społecznego i kulturalnego zgodnie ze wskazaniami religijnymi nie podważyły politycznego wpływu AKP. Mimo wyraźnego, prawie 9-procentowego spadku poparcia, a także rekordowo wysokiego wyniku opozycyjnej HDP (13,1\% głosów), AKP zdobyła w wyborach parlamentarnych w czerwcu 2015 roku aż $40,87 \%$ głosów $^{19}$.

Ekonomiczną bazą dla neoliberalnej (skrajnie wolnorynkowej, a jednocześnie moralnie restrykcyjnej) wizji AKP były tzw. "Anatolijskie tygrysy" (Anatolian Tigers): małe i średnie przedsiębiorstwa, zlokalizowane we wschodniej, konserwatywnej politycznie (i popierającej rządzącą AKP) części Turcji. Ekonomiczny cud, który stał się ich udziałem spowodował, że do głosu doszły siły i dyskursy dotychczas marginalizowane. Na temat elit biznesu, które są bardzo zorientowane na wolny rynek i nie boją się międzynarodowej konkurencji, a jednocześnie są wyraźnie konserwatywne i reprezentują przejmujące władzę w państwie środowisko islamskie, wypowiada się Soner Cagaptay - ekspert z Waszyngtońskiego Instytutu Polityki Bliskiego Wschodu. Jego zdaniem, w Turcji zachodzi obecnie prawdziwie trwała zmiana świadomościowa, nieporównywalna nawet $\mathrm{z}$ efektami, jakie niesie ze sobą zmiana rządu czy programów nauczania w szkołach. Jak twierdzi,

kraj zmienia się naprawdę, gdy zmieniają się jego milionerzy. To właśnie dzieje się obecnie w Turcji, jej elity gospodarcze ulegają transformacji. Nowa klasa posiadających reprezentuje skrajnie odmienne wartości niż dotychczas dominujące: nie są oni prozachodni, nie są proeuropejscy, a także nie do końca można ich działania wpisać $\mathrm{w}$ formułę liberalnej demokracji. Z pewnością działają $\mathrm{w}$ ramach reguł kapitalistycznych, lubią się bogacić, a AKP wykorzystuje tę nową rzeczywistość gospodar-

18 Przykładem może być uwięzienie w 2011 r. Ahmeta Şıka, dziennikarza śledczego, którego krytyczna wobec Ruchu Gülena książka pt. Imam's Army, została zakazana, a manuskrypt skonfiskowany bezpośrednio przez publikacją. Toprak oraz o Ruchu Gulena.

${ }^{19}$ O. Tekin, Turkey's 2015 election results, Today's Zeman, 2015.06 .11 (http://www.today szaman.com/blog/oguzhan-teki-n/newsDetail_openPrintPage.action?newsId=384983). 
czą do stworzenia dla siebie nowej klasy milionerów, którzy byliby wsparciem dla polityki AKP.

Zachodnioorientalny dualizm tożsamości w sposób szczególny stał się doświadczeniem kobiet $\mathrm{w}$ Turcji. Jedynymi beneficjentkami edukacyjnych i prawnych reform $w$ republikańskiej Turcji były kobiety z elit. Stały się one swoistymi "markerami narodowej nowoczesności", przejawiającej się $\mathrm{w}$ „zachodnim ubiorze" oraz towarzyszeniu mężczyznom w życiu publicznym (zwłaszcza kulturalnym). Emancypacja kobiet w Turcji została jednak ograniczona do kobiet najwyżej wykształconych, a "zachodniemu” stylowi ich życia przeciwstawiano nadal utrzymywane na prowincji "tradycyjne normy kobiecej skromności" 20 . Do lat 80 . XX wieku w dyskursie publicznym $\mathrm{w}$ Turcji dominowało niezachwiane przekonanie o emancypacji kobiet jako jednym z zasadniczych zrealizowanych idei kemalizmu. Pojawiające się w późniejszym okresie kontrowersje wokół tego tzw. kemalistycznego (państwowego) feminizmu trafnie charakteryzuje Kandiyoti w swoich tekście Emancipated but Unliberated?, która ocenia wydarzenia z okresu reform lat 20. XX wieku następująco:

Zmiany w Turcji praktycznie nie dotknęły takich zasadniczych sfer relacji płci jak podwójny standard seksualności czy domowy wymiar definiowania roli kobiecej (...). Nie pojawiły się wyraźne sygnały politycznej aktywności kobiet, zmierzające do zmiany istniejącego stanu rzeczy ${ }^{21}$.

Kwestie kobiece od początku były elementem politycznej dyskusji mężczyzn, którzy - mimo iż formalnie znieśli poligamię i przyznali kobietom równe prawa obywatelskie i polityczne - nie podważali podstawowej zasady kształtującej życie kobiet $\mathrm{w}$ Turcji: patriarchalnej dominacji mężczyzn. Zmiany prawne nie szły w parze z przemianami norm i zwyczajów, na podstawie których funkcjonowała wspólnota. Kobieta wpisana została w hierarchiczny, republikański projekt społeczny: nadrzędności państwa i jego instytucji (rodziny, systemu edukacyjnego i mediów) nad jednostką (zwłaszcza płci żeńskiej).

W latach 80. XX wieku zdecentralizowany i apolityczny kobiecy aktywizm stał się coraz bardziej widoczny, a takie tematy jak zakwestionowanie zwyczajowej roli kobiet $\mathrm{w}$ rodzinie, prawo kobiet do autoekspresji $\mathrm{w}$ życiu społecznym i zawodowym, przeciwdziałanie przemocy domowej wobec kobiet, prawo do aborcji, zaczęły być otwarcie wprowadzane do dyskursu

20 U. Azak, Islam and Secularism in Turkey, s. 12.

${ }^{21}$ E. Atakav, Women and Turkish Cinema. Gender Politics, Cultural Identity and Representation, London - New York 2013, s. 29. 
publicznego ${ }^{22}$. Mimo iż nie udało się wówczas radykalnie zmienić społeczeństwa, środowiska kobiece $\mathrm{w}$ Turcji przyczyniły się do rozwoju społeczeństwa obywatelskiego, a ich aktywizm wpłynął na publiczny dyskurs o demokracji i otworzył kanały artykulacji postulatów ich na forum politycznym. Po raz pierwszy w historii Turcji kobiety „wyartykułowały swoje problemy i żądania wolności (...), zaczęły walczyć o swoje prawa, które wcześniej zostały im jedynie w teorii nadane przez państwo" 23 .

Od momentu przejęcia władzy przez AKP sytuacja kobiet w Turcji uległa zasadniczej zmianie. Realizowana wizja państwa, oparta na założeniach islamu sannickiego, $\mathrm{w}$ połączeniu $\mathrm{z}$ otwarcie neoliberalną polityką gospodarczą, kreuje niesprzyjający klimat polityczny dla kobiet tureckich. Wskaźnik zatrudnienia kobiet $\mathrm{w}$ Turcji wynosi zaledwie $28,7 \%$, co sytuuje Turcję na jednym z ostatnich miejsc wśród państw OECD. Około 12 milionów (spośród całościowej liczby 27 milionów) kobiet tureckich powyżej 15. roku życia definiowanych jest jako "gospodynie domowe", a 3 miliony pracuje w rolnictwie; obydwie kategorie są kwalifikowane jako grupa „nieodpłatnie pracujących członków rodziny" (unpaid family workers). Jak wskazuje Özlem İlyas Tolunay,

Jeśli do tych liczb dodamy kobiety bezrobotne, chore, niepełnosprawne oraz te, które porzuciły nadzieję na znalezienie pracy, dostrzeżemy, iż ponad połowa kobiet mieszkających w Turcji nie posiada jakiegokolwiek samodzielnych dochodów. Pozostała część pracujących kobiet jest najczęściej zatrudniona w nisko płatnych sektorach²4.

Biorąc pod uwagę fakt, iż nawet wśród kobiet tureckich z wyższym wykształceniem stopa bezrobocia jest dwukrotnie wyższa niż wśród mężczyzn $(15,2-7,6 \%)$, nie tylko ekonomiczna, ale i społeczno-kulturowa pozycja kobiet w Turcji jawi się niekorzystnie. Pierwszorzędne znaczenie mają role domowe (matek, żon i sióstr), w dalszej perspektywie są role zawodowe, ograniczające się jednak do funkcjonowania jako tania siła robocza. Neoliberalny imperatyw utrzymania pozycji Turcji jako globalnego dostarczyciela taniej siły roboczej zmusza poszukujące pracy kobiety do (nierównego) konkurowania z mężczyznami. Zatrzymanie kobiet $\mathrm{w}$ domu staje się więc imperatywem ekonomicznym neoliberalnej polityki gospodarczej AKP25.

22 Tamże, s. 31.

23 Tamże, s. 37.

24 Ö. Tolunay, Women in Erdoğan's Turkey, New Politics, Volume XIV-4, Winter 2014 (http://newpol.org/content/women-erdo\%C4\%9Fan\%E2\%80\%99s-turkey).

${ }^{25}$ Mają temu służyć m.in. takie rozwiązania, jak nieoprocentowana pożyczka rządowa dla młodych małżeństw (między 18. a 24. rokiem życia) oraz prawo do odroczenia jej spłaty w sytuacji zajścia kobiety w ciążę w ciągu roku od zawarcia małżeństwa (tamże). 


\section{Neoliberalizm i desekularyzacja - dwa wymiary przemian tureckiego systemu edukacji}

Wraz z powolnym chyleniem się imperium otomańskiego ku upadkowi, sekularyzacyjne reformy Atatürka w coraz większym stopniu zaczęły obejmować edukację. Już od końca XIX wieku obowiązywał w imperium dualizm, oznaczający współwystępowanie instytucji kontrolowanych przez władze religijne obok - coraz liczniejszych - świeckich szkół, podlegających wyłącznemu nadzorowi państwa. Dualizm ów zakończył się definitywnie wraz ze zniesieniem kalifatu. Normatywną podstawą sekularyzacji edukacji w Turcji była uchwalona w 1924 roku Ustawa o unifikacji edukacji (Tevhid-i Tedrisat Kanunu), na mocy której zamknięte zostały podlegające władzom religijnym seminaria duchowne, a obowiązkowe szkoły podstawowe objęto zestandaryzowanym, świeckim programem nauczania ${ }^{26}$. Władze religijne pozbawione zostały jakichkolwiek roszczeń do kontroli edukacji, a nadzór nad szkolnictwem obowiązkowym (podstawowym, dla dzieci do 12. roku życia) sprawować miała od tej pory wyłącznie centralna władza świecka, czyli Ministerstwo Edukacji27.

Turecki system edukacyjny rekapituluje $\mathrm{z}$ powodzeniem następująca fraza: „centralizacja z niewielką autonomią szkół”28. Podstawą prawną scentralizowanej struktury zarządzania systemem edukacji w Turcji jest ustawa edukacyjna z 1973 roku (The Basic Law of National Education), przyznająca Ministerstwu Edukacji uprawnienia do decydowania o wszelkich aspektach kształcenia - od szkolnictwa podstawowego do kształcenia ustawicznego i doradztwa. Dyrektoriaty Edukacji Narodowej, reprezentujące Ministerstwo w 81 tureckich prowincjach, odpowiedzialne są za wdrażanie odgórnie ustanawianej polityki edukacyjnej. Kluczowe znaczenie dla projektowania zmian edukacyjnych ma struktura biurokratyczna na centralnym poziomie zarządzania oświatą, która obejmuje, obok Ministerstwa Edukacji Narodowej, także takie instytucje, jak m.in. Radę Oświaty (odpowiedzialną za konstruowanie programów i planów nauczania oraz zatwierdzanie podręczników szkolnych) oraz Radę Szkolnictwa Wyższego - YÖK (odpowiedzialną za politykę oraz nadzór nad instytucjami na poziomie szkolnictwa wyższego). O wysokim stopniu centralizacji tureckiego systemu edukacji może świad-

${ }^{26}$ U. Azak, Islam and Secularism in Turkey, s. 10.

${ }_{27}$ N.A.N.M. Van Os, Polygamy before and after the Introduction of the Swiss Civil Code in Turkey, [w:] The State and the Subaltern. Modernization, Society and the State in Turkey and Iran, red. T. Atabaki, New York 2007, s. 181.

28 Tytuł jednego z akapitów dokumentu OECD: Education Policy Outlook: Turkey, October 2013. 
czyć wyłączna odpowiedzialność rządu centralnego za planowanie polityki edukacyjnej, strukturę kształcenia czy współpracę instytucji edukacyjnych z rynkiem pracy. Jedynie w obszarze decyzji kadrowych (personelu pedagogicznego) oraz zarządzania finansowaniem oświaty dopuszcza się do współdecydowania władze prowincji. Szkoły wszystkich szczebli, łącznie z zawodowymi i wyższymi, są odpowiedzialne wyłącznie za organizację kształcenia zgodnie z odgórnymi wytycznymi i nie posiadają autonomii, pozwalającej na instytucjonalne wyrażanie swoich potrzeb i proponowanie zgodnych z potrzebami środowiska lokalnego - inicjatyw edukacyjnych. Dla porównania, średnia OECD w obszarze decyzji podejmowanych w ramach szkolnictwa średniego 1 . stopnia przez same szkoły wynosi $40 \%$; decyzje podejmowane przez samorząd lokalny obejmują kolejne $10 \%$. Wpływ decyzji rządu centralnego na szkolnictwo średnie 1. stopnia wynosi niecałe $40 \%$ (średnia dla OECD). W Turcji mamy do czynienia nie tylko z odwróceniem proporcji (jedynie $20 \%$ decyzji podejmowanych przez same szkoły, a aż $60 \%$ decyzji zapadających na poziomie centralnym), ale też z całkowitą nieobecnością w Turcji lokalnego poziomu podejmowania decyzji edukacyjnych ${ }^{29}$.

$\mathrm{W}$ ostatnich latach $\mathrm{w}$ Turcji dokonano istotnej zmiany strukturalnej. W 2012 roku wydłużono okres obowiązku szkolnego z 8 do 12 lat, a także zreformowano układ placówek szkolnych, wprowadzając 4-letnią szkołę podstawową oraz - również 4-letnie - szkolnictwo średnie 1. oraz 2. stopnia. Zmiany dokonywane były na podstawie "Strategicznego Planu Ministerstwa Edukacji” (2010-2014), a zmianę strukturalną popularnie nazwano „reformą $4+4+4$ ". Obowiązek szkolny trwa 12 lat i obejmuje obecnie dzieci/młodzież od 5,5 do 17,5 roku życia. Jednocześnie w opinii publicznej panuje przekonanie, iż obniżenie wieku rozpoczęcia kształcenia podstawowego (po ukończeniu 66 miesięcy) odbyło się bez należytej, merytorycznej debaty. Propozycje rządu spotkały się z wyraźnym oporem ze strony rodziców, którzy na własnej skórze odczuwali skutki pośpiesznie wdrażanych i nie konsultowanych z ekspertami oraz opinią publiczną reform. W dyskursie medialnym szczególnie krytycznie odnoszono się do słów premiera: „Są rodzice, którzy starają się o zaświadczenia zdrowotne, aby uniknąć posłania swoich dzieci do szkoły. Potępiam ich za zdradę własnych dzieci. Czy te dzieci są idiotami?"30. Arogancja władzy centralnej, połączona z brakiem konsultacji $\mathrm{w}$ procesie wdrażania zmiany strukturalnej 2012 roku w Turcji czyni z całego procesu "książkowy" przykład sterowanej politycznie refor-

29 OECD, Education Policy Outlook: Turkey 2013, October 2013, s. 16.

30 http:/ / www.hurriyetdailynews.com/constant-changes-in-education-confounding-allstakeholders.aspx?PageID=238\&NID=54484\&NewsCatID=338 [dostęp: 20.07.2015]. 
my odgórnej, pozbawionej faktycznych prób uwzględniania opinii środowiska oraz niezależnych ekspertów. Ofiarami reformy stają się zagubieni uczniowie i ich skonsternowani rodzice, a także „wykonawcy reform”: nauczyciele i dyrektorzy szkół.

Kolejnym „poligonem doświadczalnym” jest reforma systemu egzaminacyjnego, podejmowana $w$ trakcie rządów AKP w latach 2003-2013 aż sześć razy. W Turcji obserwuje się sytuację paradoksalną, w której wydłużeniu obowiązku szkolnego towarzyszy utrzymanie (wręcz wzmocnienie) mechanizmów selekcyjnych, zwłaszcza selekcji akademickiej, prowadzonej na zakończenie szkoły średniej 1. stopnia. W turecki system szkolny, mimo pozorów jednolitości (oparcia kształcenia obowiązkowego na wspólnej podstawie programowej), wpisany jest (neoliberalny) priorytet wczesnej orientacji. W Turcji, jeszcze przed wprowadzeniem reformy strukturalnej, prowadzona była wczesna selekcja akademicka, kłócąca się z jednolitym charakterem istniejącej do 2012 roku struktury szkolnej. Na fenomen ten expressis verbis wskazywał raport "Education policy Outlook: Turkey" z 2013 roku, w którym stwierdzono: „Przejście na poziom kształcenia średniego 2. stopnia oraz kształcenia wyższego jest wysoce selekcyjne" 31 .

Najważniejszym progiem selekcyjnym był następujący po ukończeniu jednolitej, ośmioletniej szkoły podstawowej i średniej 1. stopnia (dla dzieci w wieku 6-14 lat) centralnie zarządzany egzamin SBS (tur. Seviye Belirleme Sinavi; ang. Level Determination Exam). Wynik testu otwierał drzwi do najlepszych szkól, ale jednocześnie spychał do "ślepych uliczek edukacyjnych” (słabych jakościowo szkół średnich) spory odsetek populacji uczniów. Zjawisko wczesnej selekcji wzmacniał rozwinięty rynek płatnych korepetycji $\mathrm{w}$ dużych miastach (private tuto ring; tur. dersanes), skierowany do rodzin o wyższym statusie społeczno-ekonomicznym, dysponujących wystarczającymi zasobami finansowymi oraz kulturowymi. Przygotowaniem uczniów do egzaminów poprzedzających przejście do szkoły średniej (SBS) zajmowały się prywatne, wyspecjalizowane instytucje edukacyjne ${ }^{32}$. W czerwcu 2013 roku ponad milion uczniów przechodzących na poziom średni 2. stopnia po raz ostatni przystąpiło do zestandaryzowanego testu SBS. Jak stwierdził ówczesny minister edukacji, nowy system egzaminacyjny miał być wprowadzany stopniowo: „Pracujemy obecnie nad systemem, w którym egzaminy będą przeprowadzane przez Ministerstwo Edukacji, a wyniki tych egzami-

31 OECD, 2013, s. 4.

${ }^{32}$ H.K. Altinyelken, The Demand for Private Tutoring in Turkey. Unintended Consequences of Curriculum Reform [w:] Private Tutoring Across the Mediterranean. Power Dynamics and Implications for Learning and Equity, red. M. Bray, A.E. Mazawi, R.G. Sultana, Rotterdam 2013, s. 189. 
nów będą sprawiedliwie oceniane" ${ }^{\prime 3}$. Jednakże zdaniem obserwatorów, odgórna likwidacja egzaminów nie zlikwiduje przyczyny istnienia prywatnych instytucji dokształcających. Istnieją one bowiem dlatego, że system edukacyjny nie zapewnia wystarczającej jakości kształcenia. Wskazuje się również na dyskretne poparcie, jakiego sektorowi prywatnych korepetycji udzielają politycy oświatowi, powiązani z Ministerstwem Edukacji. Biorąc pod uwagę ogromną skalę prywatnych inwestycji rodziców w „rynek korepetycyjny" (szacuje się, iż uczestniczyć w nim może nawet ponad 60\% uczniów), brak reakcji władz oświatowych można uznać za traktowanie „rynku korepetycyjnego" jako funkcjonalnego względem niedofinansowanego sektora publicznego. W konsekwencji pojawiają się oskarżenia o prowadzenie przez rząd „zawoalowanej” prywatyzacji edukacji, prowadzonej jednak nie ex lege, ale de facto ${ }^{34}$.

Selekcyjny charakter kształcenia w Turcji widoczny jest nie tylko na poziomie średnim ogólnokształcącym (akademickim), ale także na poziomie szkolnictwa wyższego. Dane z 2008 roku wskazują, iż spośród 1,6 miliona osób podchodzących do ogólnonarodowego egzaminu wstępnego na studia wyższe, dostęp do instytucji kształcenia wyższego uzyskało zaledwie 265 tysięcy studentów. W efekcie, odsetek absolwentów zarówno na poziomie kształcenia średniego, jak i wyższego jest w Turcji zdecydowanie niższy aniżeli średnia OECD (tab. 1).

Tabela 1

Odsetek 25-34-latków - absolwentów szkoły średniej 2. stopnia oraz szkoły wyższej:

Turcja na tle średniej OECD (dane za rok 2011)

\begin{tabular}{|l|c|c|}
\hline & Turcja & Średnia OECD \\
\hline $\begin{array}{l}\text { Odsetek osób w wieku 25-34 z dyplomem } \\
\text { ukończenia szkoły średniej 2. stopnia (upper } \\
\text { secondary education) }\end{array}$ & $43 \%$ & $82 \%$ \\
\hline $\begin{array}{l}\text { Odsetek osób w wieku 25-34 z dyplomem } \\
\text { ukończenia szkoły wyższej (tertiary education) }\end{array}$ & $19 \%$ & $39 \%$ \\
\hline
\end{tabular}

Źródło: OECD, Education at a Glance 2013: OECD Indicators, Paris 2013 [www, dostęp: 31.03.2017].

33 http://www.todayszaman.com/national_rapid-changes-to-turkish-education-systemill-advised-say-experts_324292.html [dostęp: 20.07.2015].

${ }^{34}$ H.K. Altinyelken, The Demand for Private Tutoring in Turkey. Unintended Consequences of Curriculum Reform [w:] Private Tutoring Across the Mediterranean, s. 197-199. 
Podsumowując, jednym z najważniejszych problemów systemu edukacji w Turcji jest podniesienie jakości kształcenia i zmniejszenie nierówności edukacyjnych. System egzaminacyjny wspiera nierówności między szkołami, zwłaszcza w obliczu ogromnego znaczenia nieformalnej struktury finansowania szkół. Oprócz środków publicznych na edukację istotnym źródłem finansowania szkól, zwłaszcza $\mathrm{w}$ rejonach miejskich, są pieniądze przekazywane przez rady rodziców (parent-teacher association - PTA). Znaczne zróżnicowanie wysokości owych dobrowolnych wpłat, będące odbiciem statusu społeczno-ekonomicznego tworzącej daną szkołę społeczności, powoduje, iż istniejące już nierówności zostają wzmocnione, a „dzieci z bogatszych środowisk chodzą do lepszych szkół" 35 .

Ostatnim sygnalizowanym wymiarem tureckiej zmiany edukacyjnej jest systematyczny wzrost znaczenia szkolnictwa wyznaniowego w Turcji. Dotychczas opisane reformy wpisują się $\mathrm{w}$ wyraźnie zaznaczającą się $\mathrm{w}$ polityce tureckiego rządu tendencję do traktowania edukacji jako narzędzia modernizacji społeczeństwa $\mathrm{w}$ duchu neoliberalnym. Jednocześnie jednak turecką politykę edukacyjną spod znaku AKP charakteryzuje otwarte postrzeganie edukacji jako narzędzia polityki desekularyzacyjnej. Desekularyzacja edukacji $\mathrm{w}$ Turcji przebiega $\mathrm{w}$ dwóch wymiarach: strukturalnym (prawne i organizacyjne wsparcie dla sektora szkół wyznaniowych) oraz programowym (wprowadzenie dobrowolnych przedmiotów ukierunkowanych na „wychowanie w religii”, a także możliwość wyboru religii jako przedmiotu na egzaminie kończącym kształcenie obowiązkowe).

Przykładem ideologicznych przemian tureckiego systemu edukacji jest renesans średniego szkolnictwa wyznaniowego, którego sytuacja - przywołując kontekst historyczny - zmieniła się diametralnie wraz z upadkiem imperium osmańskiego. Po uchwaleniu w 1924 roku Ustawy o jedności edukacji (tur. Tevhid-I Tedrisat) tradycyjne szkoły religijne (medresy) zostały zamknięte, a wszystkie instytucje edukacyjne poddano ścisłej, odgórnej i świeckiej kontroli ministerstwa edukacji. We wczesnym okresie republikańskim zlikwidowano edukację religijną w szkołach publicznych, a turecki system edukacyjny przez prawie ćwierć wieku funkcjonował oparty na ściśle świeckich podstawach. Dopiero po II wojnie światowej religia pojawiła się jako opcjonalny przedmiot szkolny; najpierw na poziomie podstawowym (w 1949), a następnie na poziomie średnim 1. (1956) i 2. stopnia (1967). Obok - dostępnej jako przedmiot nieobowiązkowy do 1982 roku - edukacji

35 http://www.hurriyetdailynews.com/constant-changes-in-education-confounding-allstakeholders.aspx?PageID=238\&NID=54484\&NewsCatID=338 [dostęp: 21.07.2015]. 
religijnej, w roku 1974 wprowadzono w szkolnictwie średnim obowiązkowe nauczanie etyki ${ }^{36}$.

Jednocześnie, po proklamowaniu świeckiej republiki w 1923 roku, zezwolono na funkcjonowanie niszowych szkół wyznaniowych, nastawionych wyłącznie na kształcenie osób (głównie imamów) odpowiedzialnych za sprawowanie praktyk religijnych $\mathrm{w}$ społeczeństwie. Jednakże nawet owe szkoły religijne, działające pod nazwą Imam-Hatip Lisesi podlegały świeckiej kontroli ministerialnej. W ten sposób, jak pisze Magdalena Szkudlarek, dokonano „inkorporacji placówek kształcenia religijnego do ogólnego systemu edukacji" 37 . Sytuacja szkolnictwa wyznaniowego w Turcji stanowiła odbicie specyficznej relacji między państwem a religią (kościołem). Fatih Genç, Ina ter Avest i Siebren Miedema określają funkcjonujący od początku lat 80. XX wieku model edukacji religijnej w Turcji mianem zintegrowanego: włączającego różne światopoglądy do jednej, neutralnej wyznaniowo wspólnoty narodowej. Warto jednak pamiętać, iż turecka koncepcja laickiego państwa (i świeckiej edukacji) od początku była zdecydowanie odmienna od funkcjonującej $\mathrm{w}$ państwach zachodnioeuropejskich, na przykład we Francji. Zasada świeckości w Turcji oznaczała bowiem nie tylko - znane z doświadczeń francuskich - odseparowanie sfery politycznej i publicznej (w tym edukacyjnej) od wpływów sfery religijnej. Jej uzupełniającym elementem był jednoczesny brak uwolnienia sfery religijnej od wpływów politycznych. Skoro zatem, jak stanowi konstytucja, państwo kontroluje i aktywnie zarządza sferą religijną w Turcji, „,każda zinstytucjonalizowana wspólnota religijna (...) znajduje się pod kontrolą regulacji rządowych"38. W konsekwencji, kontrola edukacji religijnej i wychowania moralnego jest jedną ze sfer zainteresowania rządu, obok budowania i finansowania meczetów, jak również zatrudniania muzułmańskich przywódców duchowych. Zdaniem zwolenników świeckości państwa tureckiego, „kontrola religii jest jedynym sposobem na zagwarantowanie, że islam nie zdławi świeckiego charakteru państwa i jego instytucji" 39 .

${ }^{36}$ R. Kaymakcan, Religious Education in Modern Turkey in the Context of Freedom of Religion or Belief [w:] Teaching for Tolerance and Freedom of Religion of Belief, Report from preparatory seminar held in Oslo, December 7-9, 2002.

37 M. Szkudlarek, Od Atatürka do Erdoğana - ewolucja roli religii w Turcji w okresie rządów AKP, Refleksje, 2014, 9, s. 63.

38 M.F. Genç, I ter Avest, S. Miedema, Religious education in two secular multicultural societies: the Turish and Duth case compared, Procedia. Social and Behavioral Sciences, 2011, 15, s. 803.

${ }^{39}$ Tamże. 
W 1997 roku sytuacja szkół wyznaniowych w Turcji uległa zasadniczej zmianie. W efekcie wojskowego (tzw. postmodernistycznego ${ }^{40}$ ) zamachu stanu i odsunięcia od władzy rządzącej, pro-islamskiej Partii Dobrobytu (tur. Refah Partisi) ${ }^{41}$ szkoły wyznaniowe Imam-Hatip, organizowane na poziomie średnim 1 . stopnia, zostały zamknięte. Mimo iż pozostawiono szkoły religijne na poziomie średnim 2 . stopnia, przestały być one drożne, a dostęp absolwentów Imam-Hatip do studiów uniwersyteckich został drastycznie ograniczony ${ }^{42}$. Jak pisze M. Szkudlarek, w wyniku zmian warunków przyjęć na świeckie uczelnie wyższe odsetek absolwentów Imam-Hatip rozpoczynających studia wyższe drastycznie zmalał: z 75\% do $25 \%$. Będące efektem politycznego oporu wobec desekularyzacji szkolnictwa odgórne ograniczenie drożności tychże szkół wpłynęło na spadek zainteresowania szkolnictwem wyznaniowym.

Proces desekularyzacji edukacji $\mathrm{w}$ Turcji powiązany jest $\mathrm{z}$ szerszym sporem o miejsce islamu w życiu społecznym i politycznym tego muzułmańskiego, ale oficjalnie nadal laickiego kraju. Społeczeństwo w Turcji jest spolaryzowane, a podział przebiega wzdłuż linii politycznej: zwolenników i przeciwników polityki (także edukacyjnej) AKP. Ostatnie lata to szereg inicjatyw rządowych, wzmacniających islam $\mathrm{w}$ - nominalnie nadal świeckim - systemie edukacyjnym. Były premier Recep Tayyip Erdoğan, który w sierpniu 2014 roku został wybrany prezydentem Turcji, już dawno ujawnił swój polityczny plan w sferze edukacji. Pod hasłem wyborczym utworzenia "Nowej Turcji”, podczas zgromadzenia młodzieżówki AKP w 2012 roku ogłosił: "Chcemy wychować pobożne pokolenie" (dindar nesil) ${ }^{43}$. Najbardziej wyrazistym przykładem umacniania religijnego stylu życia poprzez edukację jest systematyczne rozszerzanie wpływów szkół wyznaniowych Imam-Hatip. $\mathrm{W}$ momencie przejmowania władzy przez AKP, w 2002 roku zapisanych do tych szkół było około 65 tysięcy uczniów; obecnie liczba ta

${ }^{40}$ Nazwę tę nadali zamachowi wojskowemu inicjatorzy. Cytując słowa jednego z generałów: „Po raz pierwszy mające wsparcie społeczne i działające pod wodzą tureckich sił zbrojnych organizacje pozarządowe i opozycja przeciwstawiły się siłom, które próbują zepchnąć Turcję $\mathrm{z}$ drogi laicyzmu. Był to postmodernistyczny zamach stanu, dokonany bez użycia przemocy, z wykorzystaniem siły demokratycznego ustroju i inicjatywy cywilnej" (A. Zastawna-Templin, Problem zamykania partii politycznych $w$ Turcji w kontekście starań o członkostwo w Unii Europejskiej, [w:] Turcja i Europa. Wyzwania i szanse, red. A. Szymański, Warszawa 2011, s. 58).

${ }^{41}$ Partia powstała w 1983 r. na gruzach innych delegalizowanych wcześniej partii, aby w 1995 r. wygrać wybory parlamentarne i wynieść do władzy proislamskiego premiera Necmettina Erbakana (tamże, s. 57-58).

42 C. Letsch, Turkish parents complain of push towards religious schools, "The Guardian", 12.02.2015.

${ }^{43}$ http://www.hurriyet.com.tr/gundem/19825231.asp 
waha się w granicach miliona, co stanowi około $9 \%$ wszystkich dzieci między 10. a 18. rokiem życia. Największe zmiany nastąpiły w trakcie reformy strukturalnej w latach 2010-2012, kiedy to wszystkie ogólnokształcące szkoły średnie 2. stopnia (łącznie ze szkołami Imam-Hatip) stały się szkołami zawodowymi (co pozwoliło na przekształcanie części dotychczasowych świeckich szkół w nowe instytucje o charakterze wyznaniowym). Inną istotną zmianą tamtych lat była zgoda na "transformację" świeckich szkół średnich 1. stopnia w szkoły Imam-Hatip, które od tej pory - czyli od 2012 roku - są dostępne dla dzieci od 10. roku życia ${ }^{44}$. Rozszerzanie wpływów szkolnictwa wyznaniowego powiązane zostało z reformą strukturalną " $4+4+4$ ”, zwłaszcza $\mathrm{z}$ wprowadzeniem odrębnych szkół średnich 1. stopnia. Udział uczniów w szkolnictwie wyznaniowym w Turcji wzrasta, a większość w nich (na poziomie szkoły średniej 1 . stopnia ok. 56\%) stanowią dziewczęta ${ }^{45}$.

Wraz z dojściem do władzy AKP, rząd centralny wzmocnił swoją pierwszoplanową rolę $\mathrm{w}$ procesie wytwarzania, sprawdzania i aprobowania programu nauczania oraz podręczników, również w obszarze edukacji religijnej (wychowania moralnego). Zdaniem byłego Ministra Edukacji Vehbi Dinçerler, celem prowadzonej przez AKP błyskawicznej zmiany edukacyjnej jest próba wyeliminowania efektów zmiany ideologicznej, narzuconej społeczeństwu podczas przejścia od imperium do republiki ${ }^{46}$. Równolegle z reformą strukturalną toczy się bowiem w Turcji reforma programowa, której celem jest upowszechnienie treści religijnych także w szkołach świeckich. $\mathrm{W}$ doniesieniach medialnych powtarza się informacja o presji administracji szkolnej na rodziców i uczniów, ukierunkowanej na wybór zajęć religijnych spośród zajęć opcjonalnych (przedmiotów do wyboru). Dane z roku szkolnego 2012/2013 wyraźnie wskazują na dominację fakultatywnych zajęć wyznaniowych, dostępnych dla uczniów ostatniej klasy szkoły średniej 1. stopnia. Spośród czterech najczęściej wybieranych przedmiotów fakultatywnych, trzy stanowią zajęcia ukierunkowane na przekazanie treści religijnych, na czele z najbardziej popularnym przedmiotem, jakim jest „Życie proroka Mahometa”. „Ukryty program” nasycenia kształcenia świeckiego treściami religijnymi realizowany jest najczęściej przez dyrektora szkoły, który podejmuje decyzję o ofercie dydaktycznej przedmiotów fakultatywnych, faworyzując zajęcia religijne, a „wychładzając” zainteresowanie fakultatywnymi przedmiotami niereligijnymi. W prasie można znaleźć anonimowe wypowiedzi

44 A. Christie-Miller, Erdoğan Launches Sunni Islamist Revival in Turkish Schools, "Newsweek", 2014.12.26.

45 C. Letsch, Turkish parents.

46 http://www.todayszaman.com/national_rapid-changes-to-turkish-education-system-illadvised-say-experts_324292.html [dostęp: 20.07.2015]. 
nauczycieli oraz otwarte zarzuty rodziców o wywieranie przez szkołę presji na uczniów, a nawet o automatyczne zapisywanie ich na przedmioty religijne. Jakość i treść edukacji religijnej są od wielu lat przedmiotem krytyki. Dyskusja wokół edukacyjnych podstaw demokratycznego i świeckiego państwa rozgorzała zwłaszcza po wprowadzeniu wyżej wymienionych fakultatywnych przedmiotów, realizujących model wychowania w religii. Krytycy upatrują w tym złamania zawartego w art. 24 Konstytucji Republiki Tureckiej zapisu o zakazie wykorzystywania i nadużywania religii i uczuć religijnych do „choćby częściowego oparcia podstawowego porządku prawnego, politycznego, ekonomicznego i socjalnego państwa na dogmatach religijnych" 47 .

Jednocześnie warto pamiętać, iż kontrowersje wokół edukacji religijnej obecne są w tureckim dyskursie edukacyjnym już od lat 80. XX wieku. Wówczas to, na mocy podstawy programowej dla szkolnictwa obowiązkowego z 1982 roku, przedmiotem obowiązkowym stała się projektowana jako neutralna światopoglądowo „Kultura religijna i wiedza o etyce” (tur. Din Kültürü ve Ahlak Biligisi). Podstawą jej wprowadzenia był artykuł 24 Konstytucji, poświęcony wolności sumienia i wyznania, stanowiący m.in.:

Edukacja w zakresie religii i etyki odbywa się pod nadzorem i kontrolą państwa. Nauczanie kultury religijnej i wychowanie moralne winno znajdować się w obowiązkowym programie dla szkół podstawowych i średnich. Uczęszczanie na inne zajęcia z religii jest dobrowolne, a w przypadku nieletnich pozostawione życzeniu ich opiekunów prawnych ${ }^{48}$.

Analiza centralnie uznanych podręczników do tego przedmiotu wskazuje na przyjęcie turecko-islamskiej (sunnickiej) perspektywy oraz nauczania $\mathrm{w}$ wierze islamskiej nad neutralnym światopoglądowo kształceniem o religiach. Pięcioma głównymi blokami tematycznymi, omawianymi w ministerialnych podręcznikach, są: 1) główne religie świata; 2) historia Islamu i życie proroka Mahometa; 3) sposoby praktykowania islamskich obrzędów religijnych; 4) rola religii w historii Turcji; 5) etyka islamska i dobre obyczaje. Jak wskazuje w swojej niezwykle inspirującej publikacji M. Hakan Yavuz, podręcznikowa narracja, zwłaszcza ukazująca rolę islamu w historii państwa tureckiego, łączy turecki nacjonalizm z religią muzułmańską: „Turkowie prezentowani są jako obrońcy islamu, pomiędzy miłością do ojczyzny a miłością do wiary stawia się znak równości" 49 .

${ }^{47}$ Konstytucja Republiki Tureckiej, s. 69.

48 Tamże.

${ }^{49}$ M.H. Yavuz, Islamic Political Identity in Turkey, Oxford 2003, s. 129. 
Oskarżenia o przymusową islamizację szkół są odpierane przez Ministerstwo Edukacji argumentem o czynieniu zadość oczekiwaniom społecznym, a także - uzasadnionej z perspektywy historycznej - „pozytywnej dyskryminacji" dotychczas marginalizowanego, a w niektórych okresach historycznych wręcz odgórnie zwalczanego szkolnictwa wyznaniowego (oraz treści religijnych). Zwolennicy szkolnictwa islamskiego podkreślają jego pozytywne aspekty, m.in. rozdział dziewcząt i chłopców, większą dyscyplinę, a zwłaszcza pozytywny wpływ edukacji moralnej opartej na deontologii religijnej na późniejsze postawy i zaangażowanie obywatelskie uczniów. Często powtarzanym przykładem jest obecność wielu znamienitych absolwentów szkół Imam-Hatip $\mathrm{w}$ życiu publicznym, na czele $\mathrm{z}$ najsłynniejszym $\mathrm{z}$ nich: byłym premierem i obecnym prezydentem R.T. Erdoğanem ${ }^{50}$.

\section{Podsumowanie}

Celem tekstu było zwięzłe zaprezentowanie dwoistości zmian edukacyjnych we współczesnej Turcji, ukazanych na tle niezwykle istotnego kontekstu historycznego oraz społeczno-kulturowego tureckiej zmiany edukacyjnej. Turecką politykę edukacyjną dominują dwa jedynie pozornie antynomiczne kierunki reformatorskie. $Z$ jednej strony obserwuje się silną presję na selekcję, konkurencyjność szkół oraz instalowanie w nich mechanizmów wolnorynkowych. Jednocześnie, obok wyraźnych elementów ideologii neoliberalnej, zmiany edukacyjne w Turcji prowadzone są w wyraźnie desekularyzacyjnym kierunku. Systematyczne wzmacnianie roli religii w życiu publicznym, w szczególności w edukacji, nie dokonało się „z dnia na dzieńn”. Kemalistyczna wizja sekularyzacji od początku przecież zakładała funkcjonalne sprzężenie systemu politycznego i religijnego $\mathrm{w}$ ramach procesu wzmacniania tureckiej tożsamości narodowej, a także „użycie” islamu do budowania tureckiego projektu pomostowej, "zachodnio-wschodniej” nowoczesności. Już w 1925 roku współpracownik Mustafy Kemala i twórca projektu „oświeconego islamu" Ahmet H. Akseki wskazywał w podręczniku do kształcenia religijnego tureckich żołnierzy, iż

wartości wojskowe, takie jak poświęcenie, jedność, samodyscyplina i przedkładanie interesów narodu tureckiego nad interes indywidualny, są centralne dla moralności islamskiej. Obywatele, dla Aseki'ego, są bardziej skłonni przestrzegać prawa i wierzyć w nie, jeśli owe prawa są oparte na i usankcjonowane przez etykę religijną. (...)

50 A. Christie-Miller, Erdoğan Launches Sunni Islamist Revival. 
Religia jest dla Aseki'ego konieczną podbudową republikańskiego systemu politycznego (...), pomaga narodzić się „nowoczesnej” sferze obywatelskiej w Turcji51.

Zespolenie symboli politycznych, narodowych i religijnych $\mathrm{w}$ edukacji tureckiej jest widoczne po dziś dzień i wpisuje się $\mathrm{w}$ fenomen tworzenia „religii obywatelskiej” w edukacji, głównie wykorzystując narodowotwórcze funkcje wiedzy i rytuałów religijnych. Obecnie - wyraźniej niż kiedykolwiek zaznacza się dualizm roli edukacji w Turcji: edukacji będącej narzędziem modernizacji społeczeństwa $\mathrm{w}$ duchu neoliberalnym, a jednocześnie edukacji jako instrumentu polityki desekularyzacyjnej, wzmacniającej religijnosymboliczne formy integracji społeczeństwa.

\section{BIBLIOGRAFIA}

Altinyelken H.K., The Demand for Private Tutoring in Turkey. Unintended Consequences of Curriculum Reform, [w:] Private Tutoring Across the Mediterranean. Power Dynamics and Implications for Learning and Equity, red. M. Bray, A.E. Mazawi, R.G. Sultana, Sense Publishers, Rotterdam 2013.

Atakav E., Women and Turkish Cinema. Gender Politics, Cultural Identity and Representation, Rutledge, London and New York 2013.

Azak U., Islam and Secularism in Turkey: Kemalism, Religion and the Nation State, I.B. Tauris, New York 2010.

Bray M., Private Tutoring Across the Mediterranean, Power Dynamics and Implications for Learning and Equity, red. M. Bray, A.E. Mazawi, R.G. Sultana, Sense Publishers, Rotterdam 2013.

Castells M., Siła tożsamości, Wydawnictwo Naukowe PWN, Warszawa 2009.

Christie-Miller A., Erdoğan Launches Sunni Islamist Revival in Turkish Schools, "Newsweek", 2014.12.26.

Genç M.F., Avest I ter, Miedema S., Religious education in two secular multicultural societies: the Turish and Duth case compared, Procedia. Social and Behavioral Sciences, 2011, 15.

http://www.hurriyet.com.tr/gundem/19825231.asp

http://www.hurriyetdailynews.com/constant-changes-in-education-confounding-all-

stakeholders.aspx?PageID=238\&NID=54484\&NewsCatID=338 [dostęp: 21.07.2015].

http://www.todayszaman.com/national_rapid-changes-to-turkish-education-system-illadvised-say-experts_324292.html [dostęp: 20.07.2015].

http://www.todayszaman.com/national_rapid-changes-to-turkish-education-system-illadvised-say-experts_324292.html [dostęp: 20.07.2015].

${ }^{51}$ M.H. Yavuz, Islamic Political Identity, s. 128. 
Kaymakcan R., Religious Education in Modern Turkey in the Context of Freedom of Religion or Belief, [w:] Teaching for Tolerance and Freedom of Religion of Belief, Report from preparatory seminar held in Oslo, December 7-9, 2002.

Kieniewicz J., Spotkania Wschodu, Novus Orbis, Gdańsk 1999.

Konstytucja Republiki Tureckiej, Wydawnictwo Sejmowe, Warszawa 2013, http:// libr.sejm.gov.pl/tek01/txt/konst/turcja2013.pdf [dostęp: 21.07.2015].

Letsch C., Turkish parents complain of push towards religious schools, "The Guardian", 12.02.2015.

OECD, Education at a Glance 2013: OECD Indicators, OECD Publishing, Paris 2013.

OECD, Education Policy Outlook: Turkey 2013, October 2013.

Said E., Orientalism, Pantheon, New York 1978.

Szkudlarek M., Od Atatürka do Erdoğana - ewolucja roli religii w Turcji w okresie rzadów AKP, Refleksje, 2014, 9.

Tekin O., Turkey's 2015 election results, Today's Zeman, 2015.06 .11 (http://www.today szaman.com/blog/oguzhan-teki-n/newsDetail_openPrintPage.action?newsId= 384983).

The Princeton Encyclopedia of Islamic Political Thought, red. G. Böwering, Princeton University Press, Princeton 2013.

Tolunay Ö., Women in Erdoğan's Turkey, New Politics, Volume XIV-4, Winter 2014 (http://newpol.org/content/women-erdo\%C4\%9Fan\%E2\%80\%99s-turkey).

Van Os N.A.N.M., Polygamy before and after the Introduction of the Swiss Civil Code in Turkey, [w:] The State and the Subaltern. Modernization, Society and the State in Turkey and Iran, red. T. Atabaki, Palgrave Macmillan, New York 2007

Yavuz M.H., Islamic Political Identity in Turkey, Oxford University Press, Oxford 2003.

Zastawna-Templin A., Problem zamykania partii politycznych w Turcji w kontekście starań o członkostwo w Unii Europejskiej, [w:] Turcja i Europa. Wyzwania i szanse, red. A. Szymański, Polski Instytut Spraw Międzynarodowych, Warszawa 2011.

Zeydanhoğlu W., The White Turkish Man's Burden: Orientalism, Kemalism and the Kurds in Turkey, [w:] Neo-Colonial Mentalities in Contemporary Europe? Language and Discourse in the Construction of Identities, red. G. Rings, A. Ife, Cambridge Scholars Publishers, Newcastle UK 2008. 